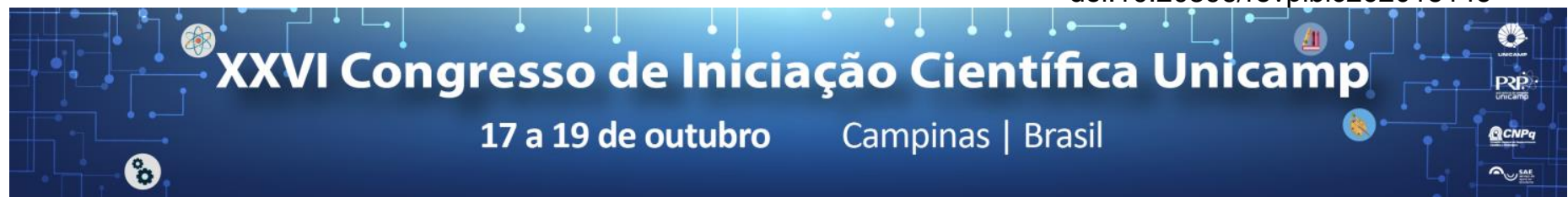

\title{
Análise do uso do biogás derivado dos resíduos da indústria da cana-de-açúcar para a cogeração de energia
}

\section{André L. Furquim, Joaquim E. A. Seabra.}

\section{Resumo}

O presente projeto avaliou a eficiência do aproveitamento energético dos resíduos da indústria da cana (vinhaça e bagaço) através da digestão anaeróbia, comparando-a com a opção convencional da queima direta do bagaço em caldeira. O desempenho de ambos os sistemas foram estimados através da modelagem termodinâmica utilizando o software EES.

\section{Palavras-chave: \\ Cogeração; Cana-de-açúcar; Resíduos; Digestão anaeróbia.}

\section{Introdução}

A preocupação com um melhor aproveitamento energético da biomassa da cana tem sido predominante nos últimos anos, estimulada principalmente pelas possibilidades do mercado de energia elétrica. Hoje as opções comerciais para a geração de energia nas usinas estão essencialmente restritas a sistemas de cogeração baseados em ciclos a vapor, os quais utilizam bagaço como combustível. Alternativamente à combustão direta, a digestão anaeróbia dos resíduos da agroindústria (incluindo vinhaça, bagaço e torta de filtro) também pode ser empregada visando à sua conversão em biogás, para posterior geração de eletricidade. O objetivo deste projeto foi avaliar a eficiência do aproveitamento energético dos resíduos da indústria da cana através da digestão anaeróbia, comparando-a com a opção convencional da queima direta do bagaço em caldeira.

\section{Resultados e Discussão}

Os desempenhos dos sistemas foram avaliados através do cálculo dos balanços de massa e energia das plantas de cogeração com o auxílio do software EES. Foi assumida uma usina de referência com demanda específica de energia por tonelada de cana processada de $500 \mathrm{~kg}$ de vapor (Saturado, 2,5 bar) e $30 \mathrm{kWh}$ de energia elétrica, para uma capacidade de processamento de 2 Mt de cana por safra e operação de $4000 \mathrm{~h}$ por safra.

As considerações feitas para os cálculos dos balanços de massa e energia associados a cada equipamento utilizado foram:

- Operação em regime permanente

- Não há perda de carga nos equipamentos

- Adiabáticos, exceto no processo e no condensador

- Efeitos de energia cinética e potencial desprezíveis

Para o modelo convencional que utiliza a combustão direta do bagaço como fonte de energia, foi considerada uma planta composta por uma caldeira, uma turbina de condensação-extração (CEST), duas bombas e um desaerador. Para esta configuração, foi avaliada uma capacidade de geração de excedente de eletricidade de $76,29 \mathrm{kWh} / \mathrm{t}$ cana e um fator de utilização de energia (FUE) igual a $74 \%$.
Na segunda configuração, o biogás produzido a partir da biodigestão do bagaço (após pré-tratamento hidrotérmico) e da vinhaça é utilizado como combustível em um moto-gerador. O motor foi modelado como um volume de controle cujos parâmetros globais de desempenho foram baseados no modelo Jenbacher Type 6 - J620 da General Eletric. Como a recuperação de calor do motor não seria suficiente para atender a demanda térmica de todo o processo (incluindo prétratamento do bagaço), foi adicionado um sistema de geração de vapor utilizando a queima direta do bagaço. Dessa forma, parte do bagaço é destinada à biodigestão, e parte para a geração de vapor. Nesse caso, a geração de eletricidade excedente da usina seria 90,39 kWh/t cana, com FUE igual a $62 \%$

\section{Conclusões}

A configuração alternativa à combustão direta, utilizando o biogás gerado pelos resíduos da produção, possui uma produção de energia elétrica bem maior que o modelo convencional, porém, ainda necessita de uma geração de vapor conjunta, pois não consegue suprir a demanda térmica.

Apesar disso, seu potencial de geração pode ser maior devido ao seu FUE de $62 \%$ menor que da combustão convencional (74\%). Esse potencial pode ser melhorado através da união dos dois ciclos, aproveitando a alta geração de energia elétrica do ciclo que utiliza o biogás como combustível com a geração de energia térmica do ciclo à vapor..

\section{Agradecimentos}

Os autores agradecem o CNPq pelo apoio financeiro. 